\title{
Guillain-Barré Syndrome After Aortic, Tricuspid and Mitral Valve Surgery
}

\author{
Amer Aldamouk ${ }^{1}$, Harneel Saini ${ }^{1}$, Lucas Henn $^{1}$, Thomas Marnejon ${ }^{1}$, and david Gemmel ${ }^{1}$ \\ ${ }^{1}$ Mercy Health St Elizabeth Youngstown Hospital
}

April 6, 2021

\begin{abstract}
Guillain-Barré syndrome (GBS) after surgery may be more common than previously recognized; however, GBS after open heart surgery is exceedingly rare. We describe a rare case of GBS occurring after aortic, tricuspid and mitral valve surgery and review the world's literature. Vigilance for GBS among post-surgical patients is needed.
\end{abstract}

\section{Guillain-Barré Syndrome After Aortic, Tricuspid and Mitral Valve Surgery}

Amer Aldamouk, MD ${ }^{1}$, Harneel Saini, $\mathrm{MS}^{2}$, Lucas W. Henn, MD ${ }^{3}$, Thomas Marnejon, DO ${ }^{1,2,4,5}$

David J. Gemmel, $\mathrm{PhD}^{6,7}$

1. Department of Internal Medicine, St. Elizabeth Youngstown Hospital, Youngstown, OH

2. Lake Erie College of Osteopathic Medicine, Erie, PA

3. Department of Surgery, St. Elizabeth Youngstown Hospital, Youngstown, OH

4. Northeastern Ohio Medical University, Rootstown, $\mathrm{OH}$

5. Ohio University Heritage College of Osteopathic Medicine

6. Department of Research, St. Elizabeth Youngstown Hospital, Youngstown, OH

7. Mercy College of Ohio, Youngstown, $\mathrm{OH}$

Please address all correspondence to Thomas Marnejon, DO, St. Elizabeth Youngstown Hospital, 1044 Belmont Avenue, Youngstown, OH, 44501, Phone: 330.480.3676, Email: Thomas_Marnejon@mercy.com , Fax: 330.480 .5953 .

Authors have no personal sponsorship, financial support or involvement with any organization(s) having a financial interest in the subject matter. Authors have no conflicts of interest. Authors verify that this manuscript is not under review by other journals. All authors have contributed to the writing, editing and preparation of this manuscript, and have reviewed it prior to submission.

Word Count: 1261

Keywords: Guillain-Barré Syndrome, Aortic, Tricuspid and Mitral Valve Surgery

Abstract: Guillain-Barré syndrome (GBS) is an acute autoimmune, inflammatory polyneuropathy of either demyelinating, axonal or mixed phenotypes. GBS typically follows an upper respiratory infection or gastrointestinal infection with diarrhea; Campylobacter jejunirepresents the best known etiology. GBS has also been associated with other viral illnesses and vaccinations. Surgery associated GBS may be more common than previously recognized. However, GBS associated with open heart surgery is exceedingly rare. We describe a rare case of GBS occurring after aortic, tricuspid and mitral valve surgery and review the world's literature.

\section{Introduction}


Guillain-Barré syndrome (GBS) is a classic example of a neuropathy secondary to disordered immunity. Aberrant B cell response to glycolipids and related conjugates results in demyelinating, axonal, or mixed nerve damage that manifests as an acute inflammatory immune-mediated polyneuropathy. (1) Clinical manifestations include tingling, progressive weakness, pain, and diminished reflexes. Although classic GBS is that of a demyelinating neuropathy with progressive ascending weakness, several clinical variants exist, including Miller Fisher syndrome, characterized by ophthalmoplegia and ataxia. (2)

Two thirds of GBS cases are preceded by an upper respiratory tract infection or diarrhea, with Campylobacter jejuni the most common etiology. (2) Vaccinations and various infectious vectors have also been associated with GBS, including Epstein-Barr virus, cytomegalovirus, varicella-zoster virus, mycoplasma, and, most recently, Zika virus. $(2,3)$

GBS incidence following surgical procedures is unknown. Previous national surveillance suggests that 5 percent of GBS patients had undergone surgery within an 8-week interval before onset. (4) However, 45 percent of those patients reported an antecedent illness within that same time period. Most recently, two retrospective case series of patients with GBS found a 9.5 and 15 percent incidence of post-surgical GBS. $(5,6)$ Thus, it appears that the incidence of post-surgical GBS may be higher than previously reported. Taken together, the most common surgical procedures in these case series were gastrointestinal and orthopedic; rarely patients develop GBS following coronary artery bypass surgery. We present a rare case of GBS associated with open heart surgery and review the extant world's literature.

\section{Case}

A 53-year-old African American man presented to the emergency room with acute dyspnea, anxiety, muscle spasms and severe pain in his mid-thoracic spine. He also reported paresthesia of his arms and legs. Past medical history was notable for recent open heart surgery with aortic valve replacement, mitral and tricuspid valve repair, and left atrial appendage exclusion 12 days prior to admission. Cardiovascular history was significant for a bicuspid aortic valve with resultant severe aortic insufficiency, severe mitral regurgitation, and mild tricuspid regurgitation with severe pulmonary hypertension and a markedly dilated tricuspid annulus. He had no significant coronary atherosclerosis. Additional medical history included end stage renal disease on hemodialysis, hypertension, chronic tophaceous gout, and hyperlipidemia. Physical exam revealed BP $176 / 94 \mathrm{mmHg}$, pulse 80 beats $/ \mathrm{min}$, temperature $97.9^{\circ} \mathrm{F}$, respiratory rate 20 , and BMI $23.89 \mathrm{~kg} / \mathrm{m}^{2}$.

Cardiovascular exam revealed a healing sternotomy scar without evidence of infection and artificial aortic valve closure on cardiac auscultation. Cardiac echocardiography showed preserved ejection fraction with a well-functioning bioprosthetic aortic valve. There was no aortic insufficiency, no mitral regurgitation, and trace to mild tricuspid regurgitation. Mean gradient for the aortic prosthesis was 10, mean mitral gradient was 2 , and mean tricuspid gradient was 1 . There was no pericardial effusion.

Breath sounds were diminished in the left lung base. He had preserved motor strength in the upper and lower extremities. Initial CXR revealed an elevated left hemi-diaphragm despite no intraoperative topical hypothermia or internal mammary harvest. Initial laboratory studies demonstrated sodium $133 \mathrm{mmol} / \mathrm{L}$, potassium $4.4 \mathrm{mmol} / \mathrm{L}$, bicarb $24 \mathrm{mmol} / \mathrm{L}$, chloride $94 \mathrm{mmol} / \mathrm{L}$, BUN $28 \mathrm{mg} / \mathrm{dl}$, Cr $5.9 \mathrm{mg} / \mathrm{dl}$, and blood glucose $93 \mathrm{mg} / \mathrm{dl}$. Complete blood count showed WBC 11.6 with neutrophilia and lymphopenia, Hb 7.0, Hct 20.8 , and platelet count 317,000 .

On hospital day two he subsequently developed progressive weakness and numbness of both lower extremities. Physical exam revealed symmetric bilateral lower extremity weakness, areflexia and a sensory level around $\mathrm{T}$ 10. Computed tomography scan of cervical, thoracic and lumbar spine demonstrated degenerative changes and osteophytes with no evidence of compression fracture, hematoma, abscess, or transverse myelitis. Lumbar puncture revealed normal opening pressure with clear fluid, protein $315 \mathrm{mg} / \mathrm{dL}$, WBC 5 cells $/ \mathrm{mm} 3, \mathrm{RBC} 0$ cells/mm3, and glucose $62 \mathrm{mg} / \mathrm{dL}$. Cerebrospinal fluid albumin was $133 \mathrm{mg} / \mathrm{dl}$ (0-35), and oligoclonal bands were negative. Acetylcholine receptor antibodies were $0.0 \mathrm{nmol} / \mathrm{L}$, and a nasopharyngeal swab for respiratory viruses was negative. 
Electrodiagnostic studies showed diffuse sensory-motor peripheral neuropathy with axonal degeneration and demyelinative changes consistent with acute inflammatory demyelinating polyneuropathy, the hallmark for Guillain-Barré Syndrome. Neurology was consulted and recommended transfer to ICU and initiation of IVIG. Stat IgA level was normal $228 \mathrm{mg} / \mathrm{dl}$ (70-400). On hospital day six the patient's respiratory status decompensated requiring intubation and mechanical ventilation. Plasmapheresis was initiated, and IVIG was discontinued. The patient's hospital stay was complicated by pneumonia, but he was extubated after 7 days. Motor strength gradually improved, he was subsequently transferred to acute rehab, and he was discharged home and ultimately regained full motor strength. Several months later the patient was able to receive a cadaveric heterotopic renal transplant without complication.

\section{Discussion}

In 1987, Renlund et al. reported the first case of CABG associated GBS in a 65 year old man who developed symptoms three days after surgery, successfully treated with plasmapheresis. (7) Since then, nine additional cases have been reported including the current case (Table 1). (8-13) While there are other extant reports of GBS following cardiothoracic surgery, the temporal precedence between surgery and GBS of 12 and 48 months seems an unlikely etiology $(14,15)$. In nine of the ten cases, patients were male; all patients developed symptoms within 15 days after surgery. All patients were successfully treated with either IVIG, plasmapheresis or plasma exchange, and demonstrated either significant improvement or complete recovery. Six patients required mechanical ventilation, as in the current case. Average age of the patients was 61.4 years; average time between the surgical procedure and symptom onset was 7.6 days (range 1-15, median 7.5 days). Only four patients in the series underwent valvular repair, one of which was replacement, as is our case. Table data suggests either increasing incidence or reporting of cardiothoracic surgery associated GBS.

National surveillance data from the Centers for Disease Control and Prevention has documented a 5 percent incidence of GBS within 8 weeks post-surgery. (4) However, 45 percent of those patients reported an antecedent illness within that same time period. There was a direct correlation between increasing age and the incidence of GBS, as well as a male preponderance. Our patient denied any preceding upper respiratory or gastrointestinal symptoms.

In a series published by Gensicke, et.al. the risk of developing GBS during 6 weeks following surgery was 13.1 times higher than the risk in the general population. (5) None of the patients in their study had prior open heart surgery. In a very recent retrospective review of 208 cases of GBS, Nagarajan et al. reported that 15 percent of patients developed postsurgical GBS within 8 weeks of surgery. (6) Median duration from the surgical procedure to the onset of first GBS symptoms was 19 days. Interestingly, 61 percent of patients had a known diagnosis of malignancy and 29 percent had an underlying autoimmune condition. Multivariate analysis demonstrated a statistically significant association of post-surgical GBS with age, malignancy, and presence of an autoimmune disorder. (6) In Nagarajan's series only one patient underwent CABG.

The mechanism and pathogenesis of GBS after cardiac surgery is unknown. Surgery may cause exposure of nerve roots leading to oncoantigen-mediated misdirection of autoimmune responses to epitopes within the peripheral nervous system. Immune dysregulation may be secondary to lipid soluble anesthetic agents. (6) Additionally, cardiopulmonary bypass has been associated with activation of complement, secretion of both pro- and anti-inflammatory cytokines (IL-8, IL-10), tumor necrosis factor (TNf- $\alpha$ ), and activation of neutrophils. (16)

GBS incidence within 8 weeks of a surgical procedure appears to be more common than previously thought. GBS following open heart surgery is exceedingly rare, perhaps under diagnosed or under reported given surveillance data incidence. Clinicians should be keenly aware of this association and quickly consider the diagnosis in any patient who develops progressive weakness, pain and diminished reflexes post-operatively.

\section{DECLARATIONS}

Authors have no personal sponsorship, financial support or involvement with any organization(s) having a financial interest in the subject matter. Authors have no conflicts of interest. Authors verify that this 
manuscript is not under review by other journals. All authors, AA, HS, LH, and TM, have contributed to the writing, editing and preparation of this manuscript, and have reviewed it prior to submission.

\section{References}

1. Hartung HP, Wilson HJ, Kieseier BC. Acute immunoinflammatory neuropathy: update on GuillainBarré syndrome. Curr Opin Neurol 2002; 15: 571-577.

2. Yuki N, Hartung HP. Guillain-Barré Syndrome. N Engl J Med 2012; 366: 2294-2304.

3. Wijdicks EF, Klein CJ. Guillain-Barré Syndrome. Mayo Clin Proc 2017; 92 (3): 467-479.

4. Hurwitz ES, et al. National surveillance for Guillain-Barré syndrome: January 1978-March 1979. Neurology 1983; 33: 150-7.

5. Gensicke H, et al. Increased incidence of Guillain-Barré syndrome after surgery. European Journal of Neurology 2012; 19: 1239-1244.

6. Nagarajan E, et al. Guillain-Barré syndrome after surgical procedures. Neurol Clin Pract 2017; 7: 1-9.

7. Renlund DG, Hanley DF, Traill TA. Guillain-Barré syndrome following coronary artery bypass surgery. Am Heart J 1987; 113(3): 844-5.

8. Hogan JC, Briggs TP, Oldershaw PJ. Guillain-Barré syndrome following cardiopulmonary bypass. International Journal of Cardiology 1992; 35: 427-428.

9. Campbell AJ, McKinlay K, Scott NB. Guillain-Barré syndrome after cardiopulmonary bypass. Journal of Cardiothoracic and Vascular Anesthesia 2009; 23(1): 82-83.

10. Algahtani H, et al. Guillain-Barré syndrome following cardiac surgery. Neurosciences 2009; 14(4): 374378.

11. Punith K SU, Rudresh K, Anil Kumar T. Guillain-Barrè syndrome following coronary artery bypass surgery. Indian J Med Spec 2011; 2(2): 157-9.

12. Cingoz F, Tavlasoglu M, Kurkluoglu M, et al. Guillain-Barré syndrome after coronary artery bypass surgery. Interact Cardiovasc Thorac Surg 2012; 15(5): 918-9.

13. Raut MS, Hanjoora VM, Chishti MA, Tewari R. Guillain-Barré syndrome after cardiac surgery: diagnostic dilemma. General Thoracic and Cardiovascular Surgery 2019; 67; 1087-1088.

14. Hekmat M, Ghaderi H, Foroughi M and Mirjafari SA. Guillain-Barré syndrome after CABG surgery: a case report. Acta Med Iran 2016; 54 (1): 76-78.

15. Eigel P, Larsen AL, van Ingen G. Pulmonary valve replacement for pulmonary thrombus formation after previous aortic valve replacement, Guillain-Barré syndrome and enterococcal sepsis. Interactive Cardiovascular and Thoracic Surgery 2005; 4:521-522.

16. Asimakopoulos G. Systemic inflammation and cardiac surgery: an update. Perfusion 2001; 16: 353-360.

Table 1. Reported GBS following Cardiothoracic Surgery

\begin{tabular}{|c|c|c|c|c|c|c|c|}
\hline Author & Year & Age & Sex & $\begin{array}{l}\text { Surgical } \\
\text { proce- } \\
\text { dure }\end{array}$ & $\begin{array}{l}\text { Onset of } \\
\text { symp- } \\
\text { toms }\end{array}$ & Treatment & Outcome \\
\hline Renlud (7) & 1987 & 65 & Male & $\begin{array}{l}\text { On pump } \\
\text { CABG }\end{array}$ & Day 3 & \multicolumn{2}{|c|}{$\begin{array}{l}\text { Plasmapheresis/Rapoilanical } \\
\text { ventilation Improvement }\end{array}$} \\
\hline Hogan (8) & 1992 & 60 & Male & $\begin{array}{l}\text { Aortic and } \\
\text { mitral valve } \\
\text { replacement }\end{array}$ & Day 15 & \multicolumn{2}{|c|}{$\begin{array}{l}\text { Plasmapheresis Rapid } \\
\text { improvement }\end{array}$} \\
\hline & & 53 & Male & CABG & Day 14 & \multicolumn{2}{|c|}{$\begin{array}{l}\text { change/mechaniorelnth, } \\
\text { ventilation } \quad \begin{array}{l}\text { fully } \\
\text { mobile }\end{array}\end{array}$} \\
\hline
\end{tabular}




\begin{tabular}{|c|c|c|c|c|c|c|c|}
\hline Author & Year & Age & Sex & $\begin{array}{l}\text { Surgical } \\
\text { proce- } \\
\text { dure }\end{array}$ & $\begin{array}{l}\text { Onset of } \\
\text { symp- } \\
\text { toms }\end{array}$ & Treatment & Outcome \\
\hline $\begin{array}{l}\text { Campbell } \\
(9)\end{array}$ & 2008 & 71 & Male & $\begin{array}{l}\text { Four vessel } \\
\text { CABG with } \\
\text { hypothermia }\end{array}$ & Day 1 & $\begin{array}{l}\text { Intravenous } \\
\text { im- } \\
\text { munoglobu- } \\
\text { lin for } 5 \\
\text { days/mechanica } \\
\text { ventilation } \\
\text { and } \\
\text { tracheostomy }\end{array}$ & $\begin{array}{l}\text { Discharged } \\
\text { after } 23 \text { days } \\
\text { indepen- } \\
\text { dently } \\
\text { alnobile }\end{array}$ \\
\hline \multirow[t]{2}{*}{$\begin{array}{l}\text { Algahtani } \\
(10)\end{array}$} & 2009 & 71 & Female & $\begin{array}{l}\text { Two vessel } \\
\text { CABG }\end{array}$ & Day 4 & $\begin{array}{l}\text { Plasmapheresis } \\
\text { /mechani- } \\
\text { cal } \\
\text { ventilation }\end{array}$ & $\begin{array}{l}\text { Prolonged } \\
\text { ICU stay, } \\
\text { discharged } \\
\text { to rehab } \\
\text { facility }\end{array}$ \\
\hline & & 77 & Male & $\begin{array}{l}\text { Emergency } \\
\text { aortic } \\
\text { valve } \\
\text { replacement }\end{array}$ & Day 11 & $\begin{array}{l}\text { Intravenous } \\
\text { immunoglobulin }\end{array}$ & $\begin{array}{l}\text { Moderate } \\
\text { nimprove- } \\
\text { ment, } \\
\text { trans- } \\
\text { ferred to } \\
\text { rehab } \\
\text { facility }\end{array}$ \\
\hline Punith (11) & 2011 & 65 & Male & $\begin{array}{l}\text { Triple vessel } \\
\text { CABG }\end{array}$ & Day 12 & $\begin{array}{l}\text { Intravenous } \\
\text { immunoglobulin }\end{array}$ & $\begin{array}{l}\text { Full } \\
\text { nneurologic } \\
\text { recovery } \\
\text { within } 12 \\
\text { weeks }\end{array}$ \\
\hline Cingoz (12) & 2012 & 67 & Male & $\begin{array}{l}\text { Off pump } \\
\text { CABG }\end{array}$ & Day 2 & Plasmapheresis & $\begin{array}{l}\text { Discharged } \\
\text { without } \\
\text { sequela on } \\
\text { the 10th } \\
\text { post } \\
\text { operative } \\
\text { day }\end{array}$ \\
\hline Raut (13) & 2018 & 32 & Male & $\begin{array}{l}\text { Hypothermic } \\
\text { bypass for } \\
\text { ruptured } \\
\text { Valsalva } \\
\text { sinus and } \\
\text { aortic } \\
\text { valve }\end{array}$ & Day 2 & $\begin{array}{l}\text { Plasmapheresis } \\
\text { mechani- } \\
\text { cal } \\
\text { ventilation }\end{array}$ & $\begin{array}{l}\text { Discharged } \\
\text { day } 28 \\
\text { stable }\end{array}$ \\
\hline $\begin{array}{l}\text { Aldamouk, } \\
\text { Present case }\end{array}$ & 2018 & 53 & Male & $\begin{array}{l}\text { Aortic valve } \\
\text { mitral and } \\
\text { replacement, } \\
\text { tricuspid } \\
\text { repair }\end{array}$ & Day 12 & $\begin{array}{l}\text { Intravenous } \\
\text { im- } \\
\text { munoglobu- } \\
\text { lin for } 2 \\
\text { days } \\
\text { followed by } \\
\text { plasmapheresis }\end{array}$ & $\begin{array}{l}\text { ICU } \\
\text { mechanical } \\
\text { ventilation } \\
\text { and } \\
\text { complete } \\
\text { recovery } \\
\text { within } 6 \\
\text { weeks }\end{array}$ \\
\hline
\end{tabular}

